\title{
The effects of introduction of a fungal glutamate dehydrogenase gene $(g d h A)$ on the photosynthetic rates, biomass, carbon and nitrogen contents in transgenic potato
}

\author{
Tomohito Egami ${ }^{1}$, Masataka Wakayama ${ }^{1}$, Naohiro Aoki ${ }^{1}$, Haruto Sasaki ${ }^{2}$, \\ Hiroaki Kisaka ${ }^{3}$, Tetsuya Miwa ${ }^{4}$, Ryu Ohsugi ${ }^{1, *}$ \\ ${ }^{1}$ Graduate School of Agricultural and Life Sciences, The University of Tokyo, Tokyo 113-8657, Japan; ${ }^{2}$ Institute for Sustainable \\ Agro-ecosystem Services, Graduate School of Agricultural and Life Sciences, The University of Tokyo, Tokyo 188-0002, \\ Japan; ${ }^{3}$ Production and Technology Administration Center, Ajinomoto Co. Inc., Kawasaki, Kanagawa 210-8681, Japan; \\ ${ }^{4}$ Frontire Research Laboratories, Institute for Innovation, Ajinomoto Co. Inc., Kawasaki, Kanagawa 210-8681, Japan \\ *E-mail: aohsugi@mail.ecc.u-tokyo.ac.jp Tel: +81-3-5841-5193Fax: +81-3-5841-8048
}

Received December 27, 2011; accepted January 27, 2012 (Edited by T. Demura)

\begin{abstract}
Glutamate dehydrogenase (GDH) catalyzes the reversible amination of 2-oxoglutarate with ammonium to form glutamate. GDH functions in nitrogen assimilation in microorganisms, such as Aspergillus nidulans. However, in plants, glutamine synthetase, not GDH, carries out nitrogen assimilation. Here, we report the effects of introduction of the $g d h A$ gene, encoding $\mathrm{NADP}(\mathrm{H})$-dependent glutamate dehydrogenase, from A. nidulans into potato. We analyzed the resulting changes of photosynthesis, biomass, carbon and nitrogen contents under control and low-nitrogen conditions at the flowering stage and the tuber-bulking stage. There were higher NADP(H)-GDH activities in GDH potato leaves than in the wild type. Regardless of nitrogen conditions, photosynthetic rates and soluble protein concentrations of leaves increased in GDH potatoes at the flowering stage. High photosynthetic rates remained at the tuber-bulking stage in GDH potatoes. The number and dry weight of tubers also increased in GDH potatoes. Under the low-nitrogen condition in particular, carbon and nitrogen contents of GDH potato tubers increased compared with those of the wild type. This resulted from higher rates of carbon and nitrogen redistribution to tuber in GDH potatoes than in wild-type potatoes. Our findings show that the $g d h A$ gene is a powerful tool to increase tuber dry matter and improve efficiency of nitrogen use of potato.
\end{abstract}

Key words: Biomass, carbon and nitrogen contents, glutamate dehydrogenase, potato, tuber.

Nitrogen is an essential nutrient for plants. The production of a high crop yield often requires application of a substantial amount of nitrogen fertilizer. Excess nitrogen resulting from a high level of fertilizer use has been considered as a cause of environmental pollution through eutrophication of water systems, such as rivers and groundwater, as well as emission of nitrogen oxide into air (Vitousek et al. 1997). Therefore, improvement of the nitrogen use efficiency (NUE) of crops is one possible solution to reduce nitrogen fertilizer application and environmental pollution.

Most plants take up inorganic nitrogen as $\mathrm{NO}_{3}^{-}$or $\mathrm{NH}_{4}^{+}$. Assimilation of ammonium into amino acids involves coupled reactions catalyzed by two enzymes: glutamine synthetase (GS; EC 6.3.1.2) and glutamate synthase (GOGAT; EC1.4.7.1 and EC 1.4.1.14) (Lea and Miflin 1974). GS catalyzes the ATP-dependent condensation of ammonium with glutamate to produce glutamine (Ireland and Lea 1999). Since the discovery of the GS and GOGAT pathway in plants in the 1970s, there has been debate on the role of glutamate dehydrogenase $(\mathrm{GDH}$; EC 1.4.1.2 and EC 1.4.1.4) in ammonium assimilation. GDH catalyzes the reversible amination of 2-oxoglutarate (2-OG) with $\mathrm{NH}_{4}^{+}$to form glutamate in the presence of $\mathrm{NAD}(\mathrm{P}) \mathrm{H}$ as a cofactor (Wootton 1983). However, there are at least two distinct enzymes for GDH: NAD(H)-GDH (EC 1.4.1.2) and NADP(H)-GDH.

Among these two isoenzymes, there are few reports of NADP(H)-GDH activity in plants. Although Lactuca sativa showed this activity in chloroplasts and mitochondria, its precise role in nitrogen metabolism is not well understood (Lea and Thurman 1972). On the other hand, in microorganisms, such as bacteria and fungi, studies showed that NADP(H)-GDH and GS play important roles in ammonium assimilation (Kanamori et al. 1987; Kinghorn and Pateman 1973). Therefore, the introduction of NADP(H)-GDH into plants could promote their nitrogen assimilation.

Abbreviations: GDH, glutamate dehydrogenase; GOGAT, glutamate synthase; GS, glutamine synthetase; NUE, nitrogen use efficiency. 
On the basis of this hypothesis, in previous studies, researchers introduced a bacterial or fungal $\mathrm{NADP}(\mathrm{H})$ GDH gene, $g d h A$, into various crops. Leaf biomass increased in tobacco upon over-expression of the $g d h A$ gene from Escherichia coli (Ameziane et al. 2000). In Zea mays, over-expression of the E. coli gdhA gene improved drought tolerance and increased the yield in dry conditions (Lightfoot et al. 2007). In another study, over-expression of the $g d h A$ gene from Aspergillus nidulans altered the concentrations of some free amino acids in fruits of transgenic tomato plants (Kisaka and Kida 2003). We introduced $A$. nigar gdhA gene into rice plants and, using tracer experiments involving feeding with ${ }^{15} \mathrm{NH}_{4}^{+}$, found that the transgenic rice, with the help of endogenous GS, directly assimilated $\mathrm{NH}_{4}^{+}$absorbed from the roots, leading to better growth and higher grain yield than in a control line (Abiko et al. 2010). These studies suggested that the introduction of $g d h A$ gene into higher plants increased growth and yield by enhancing the assimilation of ammonium.

In this study, we introduced the $g d h A$ gene from $A$. nidulans into potato, the fourth most widely produced crop globally after maize, rice and wheat, and evaluated the effects of its expression on photosynthetic rates, biomass production and nitrogen distribution in the transgenic potato plants (GDH potato). We found an increase of tuber dry weight and improvement of NUE in $\mathrm{GDH}$ potato lines.

\section{Materials and methods}

\section{Generation of over-expressed gdhA gene in potato}

The gene for NADP-dependent GDH ( $g d h A)$ was isolated from Aspergillus nidulans Aj no. 117192 as previously described by Kisaka and Kida (2003). Its amplified cDNA fragment was introduced into a plasmid vector, which is shown in Figure 1A. In this study, the mitochondrial transit peptide derived from tomato GDH was combined in front of the $g d h A$ gene. The gdhA was introduced into potato (Solunum tuberosum L., cv. May Queen) by the same methods as previously reported (Kisaka and Kida 2003) using a micro-tuber disc inoculation technique (Snyder and Belknap 1993). The tuber discs produced from germfree potato micro-tubers were regenerated on Murashige-Skoog medium supplemented with $2 \mathrm{mgl}^{-1}$ trans-zeatin and $0.1 \mathrm{mgl}^{-1}$ indole acetic acid for 24 hours at $25^{\circ} \mathrm{C}$. The constructed plasmid (Figure 1A) was introduced into these discs by Agrobacterium-mediated gene transformation; subsequently, the discs were planted on MS medium with $2 \mathrm{mgl}^{-1}$ trans-zeatin, $0.1 \mathrm{mgl}^{-1}$ indole acetic acid, $50 \mathrm{mgl}^{-1}$ kanamycin and $300 \mathrm{mgl}^{-1}$ cefotaxime. In the next stage, kanamycin-resistant variants were selected and regenerated. Finally, these variants were planted in soils and the tubers of five independent transgenic lines were obtained.
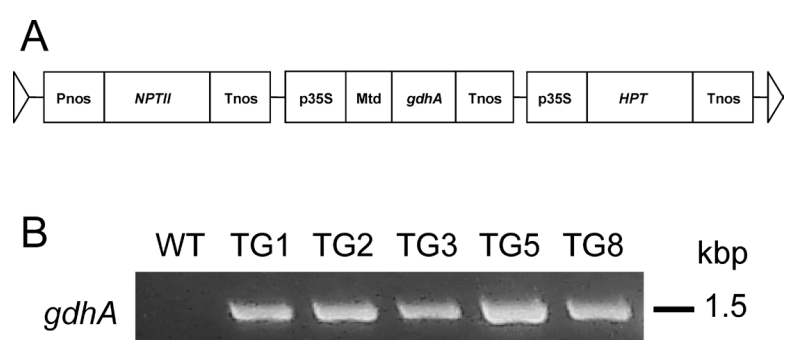

Figure 1. Generation of transgenic potato plants expressing $A$. nidulans gdhA. (A) The plasmid construct for the transformation. $g d h A$, gene for glutamate dehydrogenase from A. nidulans; Mtd, gene for mitochondrial transit peptide derived from tomato GDH; Pnos, promoter of gene for nopaline synthase; Tnos, transcription terminator region of the gene for nopaline synthase; $\mathrm{p} 35 \mathrm{~S}$, promoter of $35 \mathrm{~S}$ transcript from cauliflower mosaic virus; NPTII gene, gene for neomycin phosphotransferase; HPT, gene for hygromycin phosphortransferase. (B) Genomic PCR analysis with $g d h A$-specific primer. Flowering-stage leaves of wild type (WT) and those of five transgenic GDH potatoes (TG) were used for the analysis.

\section{Plant growth conditions}

These five transgenic lines, TG1, 2, 3, 5 and 8, as well as a nontransgenic line, wild type (WT; cv. May Queen), were planted in pots in a greenhouse in Nishi-Tokyo City, Tokyo, Japan (Institute for Sustainable Agro-ecosystem Services, Graduate School of Agricultural and Life Science, The University of Tokyo, $35.7^{\circ} \mathrm{N}, 139.5^{\circ} \mathrm{E}$ ). The temperature was set to $21^{\circ} \mathrm{C}$ during the day and $17^{\circ} \mathrm{C}$ at night with $60 \%$ relative humidity under natural light conditions from April to August. The potatoes were cultivated in 1/2000-are pots with red soil, vermiculite and perlite $(10: 3: 2 \mathrm{v} / \mathrm{v})$. Under the control nitrogen condition, $5 \mathrm{~g}$ of nitrogen, $5 \mathrm{~g}$ of phosphoric acid and $5 \mathrm{~g}$ of potassium per pot were added as basal fertilizer. Under the low-nitrogen condition, $1 \mathrm{~g}$ of nitrogen, $5 \mathrm{~g}$ of phosphoric acid and $5 \mathrm{~g}$ of potassium per pot were added as basal fertilizer. Shoot germination was restricted to one shoot by the removal of extra shoots. At the flowering stage (5 weeks after germination) and tuber-bulking stage (14 weeks after germination), potatoes were harvested and used for the following analyses.

\section{Photosynthetic rate analysis}

The fully developed leaves of the third node from the top of plants were used to measure the photosynthetic rate using a portable $\mathrm{CO}_{2}$ gas analyzer, CIRAS-1 (PP SYSTEMS, MA, USA), at $21^{\circ} \mathrm{C}, 60 \%$ relative humidity and a photosynthetic photon flux density of $1000 \mu \mathrm{mol}$ photons $\mathrm{m}^{-2} \mathrm{~s}^{-1}$. Photosynthetic rates were measured at both flowering stage and tuber-bulking stage.

\section{Isolation of DNA and analysis by PCR}

Total DNA was prepared from the leaves of GDH and wild-type potatoes at the flowering stage by a modified CTAB method (Doyle JJ and Doyle JL 1990). Amplification by PCR was carried out using two $g d h A$-specific primers: $5^{\prime}$-ATG TCT AAC CTT CCC GTT- $3^{\prime}$ and 5' -TCA CCA CCA GTC ACC CTG-3', with 30 cycles of incubation at $94^{\circ} \mathrm{C}$ for $30 \mathrm{~s}, 55^{\circ} \mathrm{C}$ for $30 \mathrm{~s}$ and 
$72^{\circ} \mathrm{C}$ for $60 \mathrm{~s}$, with a final extension at $72^{\circ} \mathrm{C}$ for $2 \mathrm{~min}$.

\section{Enzyme assays}

After the measurements of photosynthetic rates, the leaves were collected in liquid nitrogen and stored at $-80^{\circ} \mathrm{C}$. The frozen leaves were powdered under liquid nitrogen and were homogenized using an extraction buffer: $100 \mathrm{mM}$ HEPES$\mathrm{NaOH}$ (pH 7.5), 1 mM EDTA (pH 7.5), 1 mM PMSF, $10 \mu \mathrm{M}$ leupeptin, $10 \%$ glycerol (v/v), 0.2\% 2-mercaptoethanol (v/v) and $0.2 \%$ Triton $\mathrm{X}-100(\mathrm{v} / \mathrm{v})$. The homogenized tissues were centrifuged at $15,000 \mathrm{rpm}$ for $20 \mathrm{~min}$ at $4^{\circ} \mathrm{C}$. The supernatants were then desalted using Sephadex G-25 (GE Healthcare, Buckinghamshire, UK) and various activities were measured. Enzyme activities were measured by the methods described by Abiko et al. (2010). The amination activity of NAD(P) $\mathrm{H}-\mathrm{GDH}$ was determined in a reaction mixture $(1.0 \mathrm{ml}$ final volume) containing $200 \mathrm{mM}$ Tris- $\mathrm{HCl}, 5 \mathrm{mM}$ 2-oxoglutarate,

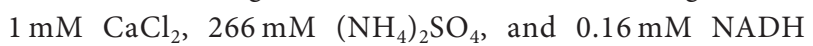
(NADH amination) or $0.2 \mathrm{mM}$ NADPH (NADPH amination) at $\mathrm{pH}$ 8.0. The deamination activity of $\mathrm{NAD}(\mathrm{P})-\mathrm{GDH}$ was determined using a reaction mixture $(1.0 \mathrm{ml}$ final volume) containing $100 \mathrm{mM}$ Tris- $\mathrm{HCl}, 50 \mathrm{mM}$ L-glutamate, $1 \mathrm{mM}$ $\mathrm{CaCl}_{2}$, and $3 \mathrm{mM}$ NAD (NAD deamination) or $1 \mathrm{mM}$ NADP (NADP deamination) at $\mathrm{pH}$ 8.5. The NADP(H)-GDH and $\mathrm{NAD}(\mathrm{H})-\mathrm{GDH}$ activities of recombinant $g d h A$ protein were measured by monitoring the change in absorbance at $340 \mathrm{~nm}$ with a spectrophotometer (D640, Beckman Coulter, Fullerton, CA, USA). Soluble protein was measured by Bradford protein assay (Bradford 1976), using a Protein Assay Kit (Bio-Rad Laboratories, Hercules, CA, USA) and bovine serum albumin as a standard.

\section{Biomass and nitrogen analysis}

The potato plants at the tuber-bulking stage were harvested and separated into leaves, stem and tubers. The number of tubers and the tuber fresh weight were determined. Each part of the sampled plant were then dried for at least $48 \mathrm{~h}$ in an oven at $80^{\circ} \mathrm{C}$ to measure the dry weight. Subsequently, the dried samples were powdered using a sample mill (Ti-200, CMT, Japan), and their carbon and nitrogen contents were analyzed using an NC analyzer (FLASH EA, Thermo Fisher Scientific, San Jose, CA, USA).

\section{Results}

\section{Expression of $A$. nidulans gdhA in transgenic potato plants}

The genomic PCR analysis on potato leaves detected A. nidulans $g d h A$ in all five independent lines of GDH potatoes, but not in the wild-type potato (Figure $1 \mathrm{~B}$ ). To confirm the function of the introduced $g d h A$ in $\mathrm{GDH}$ potatoes, we analyzed the in vitro GDH activities in leaves sampled at the flowering stage. In the wild type, there was more than tenfold higher $\mathrm{NAD}(\mathrm{H})$ $\mathrm{GDH}$ activity than that of $\operatorname{NADP}(\mathrm{H})-\mathrm{GDH}$, in both amination and deamination directions (Figure 2A, B). In GDH potatoes, there was 5-fold higher $\mathrm{NADP}(\mathrm{H})$ GDH activity than that in the wild type, also in both directions, while there was no significant difference in $\mathrm{NAD}(\mathrm{H})-\mathrm{GDH}$ activities between GDH potatoes and the wild type. These data indicated that the introduction of $A$. nidulans $g d h A$ resulted in high NADP(H)-GDH activities and that this introduction did not affect the expression of endogenous $\mathrm{NAD}(\mathrm{H})-\mathrm{GDH}$ in transgenic potato plants. Both GDH and wild-type potatoes showed high amination activities compared with deamination activities.

In both wild-type and GDH potatoes, there were higher soluble protein concentrations in the leaves under the control nitrogen condition than those under the low-nitrogen condition (Figure 2C). Regardless of the nitrogen condition, there were higher soluble protein concentrations in GDH potatoes than in the wild type (Figure 2C).

\section{Photosynthetic rates in the leaves of wild-type and transgenic potato plants}

Regardless of the nitrogen conditions, there were significantly higher photosynthetic rates of all GDH potato leaves than those of wild-type leaves at the flowering stage (Figure 3). In the wild-type leaves, there was a lower photosynthetic rate in the low-nitrogen condition than in the control nitrogen condition. Interestingly, most of the GDH potatoes did not show such a decrease in photosynthetic rate under the lownitrogen condition (Figure 3).

The photosynthetic rates of potato leaves during the tuber-bulking stage declined compared with those at the flowering stage (Figure 3). Most GDH potato lines maintained higher photosynthetic rates than the wild type under both control and low-nitrogen conditions (Figure 3). In an exceptional case, there was a significantly lower photosynthetic rate of TG5 leaf at the tuber-bulking stage than that of wild-type leaf under the control condition, although we cannot interpret the inhibitory effect on photosynthesis by the introduction of $g d h A$ at present.

\section{Biomass of GDH potatoes at tuber-bulking stage}

Under the control nitrogen condition, there was a tendency for an increase in the number of tubers in GDH potatoes, although a significant difference was shown only between one of the GDH potato lines (TG3) and the wild type (Table 1). GDH potatoes showed low leaf dry weight compared with the wild type. GDH potatoes also tended to have higher stem dry weight, tuber dry weight and total dry weight.

Under the low-nitrogen condition, GDH potatoes showed a clearer tendency for increase in the number of tubers than under the control nitrogen condition. 

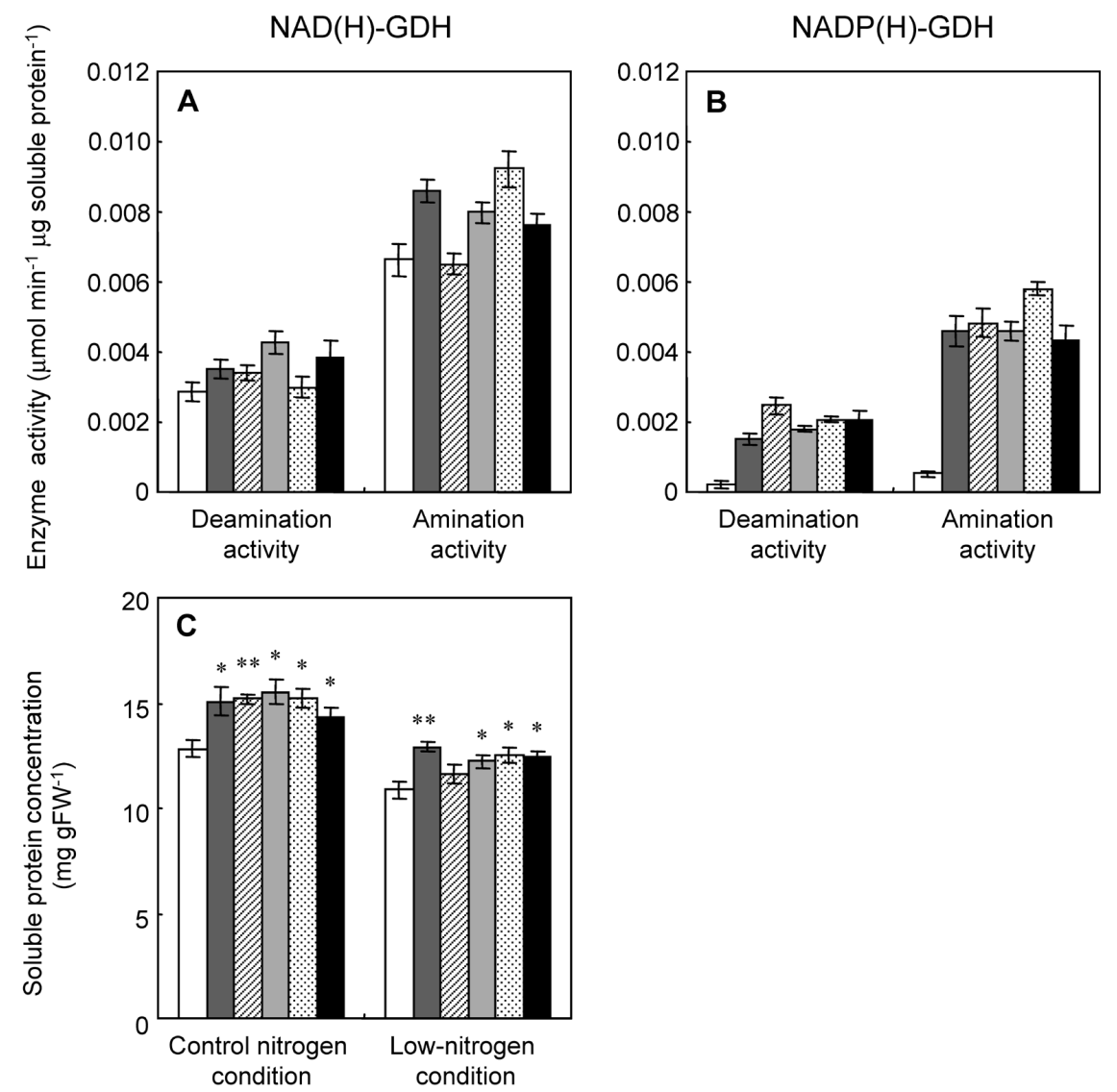

WT

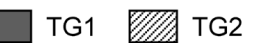

TG3

TG5

TG8

Figure 2. In vitro $\mathrm{NAD}(\mathrm{H})-\mathrm{GDH}$ activities $(\mathrm{A}), \mathrm{NADP}(\mathrm{H})-\mathrm{GDH}$ activities $(\mathrm{B})$ and soluble protein concentrations (C) of GDH potato leaves. The leaves were analyzed at the flowering stage under the control nitrogen condition. Amination activities of NADH-GDH and NADPH-GDH were measured at $\mathrm{pH} 8.0$ with the addition of NADH or NADPH. Deamination activities of NAD-GDH and NADP-GDH were measured at pH 8.5 with the addition of NAD or NADP. The soluble protein concentrations of GDH potato leaves were measured at the flowering stage under the control and low-nitrogen conditions. Data represent the mean values $\pm S E(n=4)$. Asterisks indicate significant difference of the mean of each transgenic line from that of the wild type at $P<0.05(*)$ and $P<0.01(* *)$.

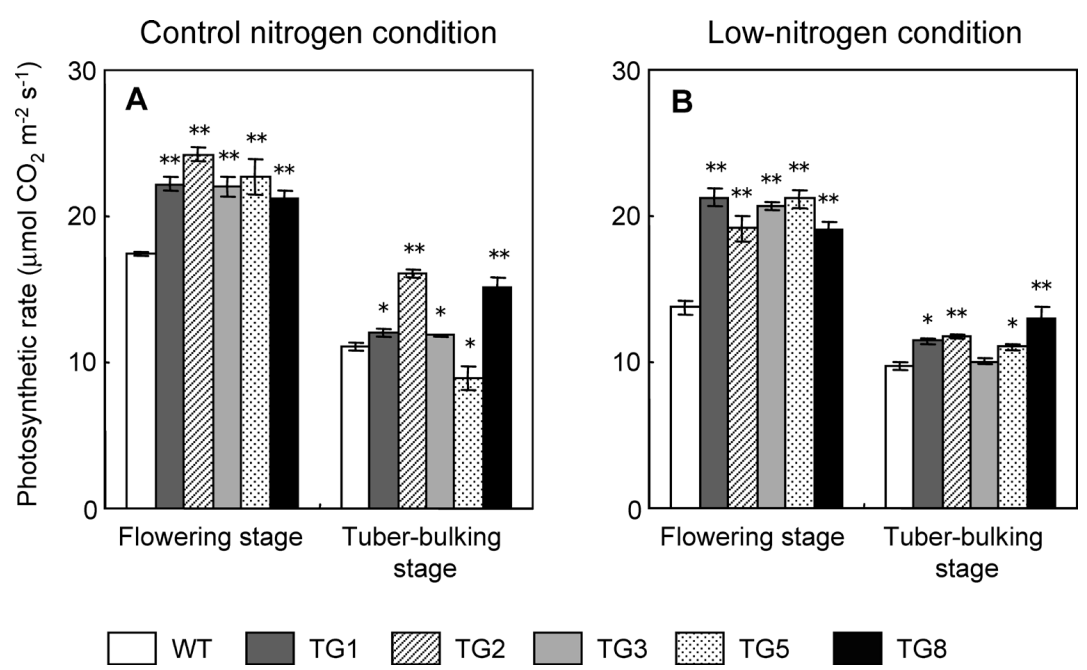

Figure 3. The photosynthetic rates of wild-type and GDH potato leaves under the control nitrogen condition (A) and the low-nitrogen condition (B). The photosynthetic rates were measured at the flowering stage and the tuber-bulking stage. Data represent the mean values \pm SE $(n=4)$. Asterisks indicate significant difference of the mean of each transgenic line from that of the wild type at $P<0.05(*)$ and $P<0.01(* *)$. 
Table 1. Number of tubers, biomass and tuber dry matter ratio of wild-type and GDH potatoes

\begin{tabular}{|c|c|c|c|c|c|c|}
\hline Line & WT & TG1 & TG2 & TG3 & TG5 & TG8 \\
\hline \multicolumn{7}{|c|}{ Control nitrogen condition } \\
\hline Number of tubers & $\begin{array}{l}6.5 \pm 1.19 \\
(100.00)\end{array}$ & $\begin{array}{c}11.75 \pm 1.65 \\
(180.77)\end{array}$ & $\begin{array}{c}9.75 \pm 1.49 \\
(150.00)\end{array}$ & $\begin{array}{l}14 \pm 1.0801 * \\
(215.38)\end{array}$ & $\begin{array}{c}11.25 \pm 2.36 \\
(173.08)\end{array}$ & $\begin{array}{c}7.75 \pm 1.03 \\
(119.23)\end{array}$ \\
\hline Leaf dry weight (g) & $\begin{array}{c}17.95 \pm 0.73 \\
(100.00)\end{array}$ & $\begin{array}{c}13.88 \pm 0.78^{*} \\
\quad(77.35)\end{array}$ & $\begin{array}{c}13.38 \pm 0.84^{*} \\
(74.53)\end{array}$ & $\begin{array}{l}15.90 \pm 1.04 \\
\quad(88.61)\end{array}$ & $\begin{array}{l}17.70 \pm 1.32 \\
\quad(98.61)\end{array}$ & $\begin{array}{l}9.98 \pm 0.48^{* * *} \\
(55.60)\end{array}$ \\
\hline Stem dry weight (g) & $\begin{array}{c}10.47 \pm 3.35 \\
\quad(100.00)\end{array}$ & $\begin{array}{c}11.92 \pm 0.93 \\
\quad(113.80)\end{array}$ & $\begin{array}{c}12.64 \pm 0.93 \\
\quad(120.72)\end{array}$ & $\begin{array}{c}10.70 \pm 0.44 \\
(102.15)\end{array}$ & $\begin{array}{c}16.43 \pm 2.01 \\
(156.86)\end{array}$ & $\begin{array}{c}7.52 \pm 0.35 \\
(71.78)\end{array}$ \\
\hline Tuber dry weight (g) & $\begin{array}{c}109.40 \pm 7.70 \\
(100.00)\end{array}$ & $\begin{array}{c}146.70 \pm 5.49^{*} \\
(134.09)\end{array}$ & $\begin{array}{c}118.83 \pm 5.01 \\
(108.62)\end{array}$ & $\begin{array}{c}127.01 \pm 8.96 \\
(116.10)\end{array}$ & $\begin{array}{c}126.64 \pm 1.23 \\
(115.76)\end{array}$ & $\begin{array}{c}121.49 \pm 2.11 \\
(111.05)\end{array}$ \\
\hline Total dry weight (g) & $\begin{array}{c}137.82 \pm 4.16 \\
(100.00)\end{array}$ & $\begin{array}{c}172.50 \pm 6.51^{*} \\
(125.16)\end{array}$ & $\begin{array}{c}144.85 \pm 4.27 \\
(105.10)\end{array}$ & $\begin{array}{c}153.61 \pm 7.96 \\
(111.46)\end{array}$ & $\begin{array}{c}160.77 \pm 2.45^{*} \\
(116.65)\end{array}$ & $\begin{array}{c}138.98 \pm 2.78 \\
(100.84)\end{array}$ \\
\hline Tuber dry matter ratio & $\begin{array}{c}20.71 \pm 0.68 \\
\quad(100.00)\end{array}$ & $\begin{array}{c}22.02 \pm 0.45 \\
\quad(106.31)\end{array}$ & $\begin{array}{c}19.98 \pm 1.00 \\
(96.50)\end{array}$ & $\begin{array}{c}19.46 \pm 1.44 \\
(93.99)\end{array}$ & $\begin{array}{c}20.35 \pm 0.39 \\
(98.25)\end{array}$ & $\begin{array}{c}20.25 \pm 0.34 \\
(97.79)\end{array}$ \\
\hline \multicolumn{7}{|c|}{ Low-nitorogen condition } \\
\hline Number of tubers & $\begin{array}{c}6.50 \pm 1.50 \\
(100.00)\end{array}$ & $\begin{array}{c}9.25 \pm 1.25 \\
(142.31)\end{array}$ & $\begin{array}{c}9.75 \pm 1.03 \\
(150.00)\end{array}$ & $\begin{array}{l}13.25 \pm 0.48^{* *} \\
(203.85)\end{array}$ & $\begin{array}{c}9.25 \pm 0.75 \\
(142.31)\end{array}$ & $\begin{array}{c}11.00 \pm 1.08 * \\
(169.23)\end{array}$ \\
\hline Leaf dry weight (g) & $\begin{array}{c}15.51 \pm 0.94 \\
(100.00)\end{array}$ & $\begin{array}{c}10.35 \pm 2.01 * \\
\quad(66.73)\end{array}$ & $\begin{array}{l}12.53 \pm 0.56 \\
\quad(80.81)\end{array}$ & $\begin{array}{c}12.62 \pm 0.69 \\
\quad(81.38)\end{array}$ & $\begin{array}{l}12.91 \pm 0.35 \\
\quad(83.25)\end{array}$ & $\begin{array}{c}10.13 \pm 0.71^{*} \\
(65.31)\end{array}$ \\
\hline Stem dry weight (g) & $\begin{array}{c}8.69 \pm 0.35 \\
(100.00)\end{array}$ & $\begin{array}{c}7.27 \pm 0.95 \\
(83.63)\end{array}$ & $\begin{array}{c}9.65 \pm 0.78 \\
(111.05)\end{array}$ & $\begin{array}{c}9.06 \pm 1.92 \\
(104.26)\end{array}$ & $\begin{array}{c}10.48 \pm 0.73 \\
(120.58)\end{array}$ & $\begin{array}{c}7.07 \pm 0.28^{*} \\
(81.38)\end{array}$ \\
\hline Tuber dry weight (g) & $\begin{array}{c}84.25 \pm 2.44 \\
\quad(100.00)\end{array}$ & $\begin{array}{c}107.09 \pm 8.96 \\
(127.11)\end{array}$ & $\begin{array}{c}128.74 \pm 3.85^{* *} \\
(152.81)\end{array}$ & $\begin{array}{c}119.08 \pm 5.53 * * \\
(141.34)\end{array}$ & $\begin{array}{c}123.19 \pm 4.56^{* * *} \\
(146.22)\end{array}$ & $\begin{array}{c}110.75 \pm 5.34^{* *} \\
(131.46)\end{array}$ \\
\hline Total dry weight (g) & $\begin{array}{c}108.45 \pm 2.23 \\
(100.00)\end{array}$ & $\begin{array}{c}124.70 \pm 11.05 \\
(114.99)\end{array}$ & $\begin{array}{c}150.92 \pm 4.16^{* *} \\
(139.17)\end{array}$ & $\begin{array}{c}140.76 \pm 4.89 * * \\
(129.79)\end{array}$ & $\begin{array}{c}146.57 \pm 4.30^{* *} \\
\quad(135.16)\end{array}$ & $\begin{array}{c}127.95 \pm 5.19^{* *} \\
\quad(117.98)\end{array}$ \\
\hline Tuber dry matter ratio & $\begin{array}{c}16.55 \pm 1.71 \\
(100.00)\end{array}$ & $\begin{array}{c}18.26 \pm 1.42 \\
\quad(110.32)\end{array}$ & $\begin{array}{c}22.23 \pm 0.45 \\
\quad(134.27)\end{array}$ & $\begin{array}{c}19.96 \pm 0.62 \\
\quad(120.58)\end{array}$ & $\begin{array}{c}20.86 \pm 0.55 \\
\quad(126.00)\end{array}$ & $\begin{array}{c}20.06 \pm 0.96 \\
\quad(121.17)\end{array}$ \\
\hline
\end{tabular}

Tuber dry matter ratio was calculated by the percentage of dry weight for flesh weight. Figures in parentheses show ratio to the wild-type level (as 100$)$. Data represent the mean values $\pm \operatorname{SE}(\mathrm{n}=4)$. Asterisks indicate that the mean of each transgenic line is significantly different from that of the wild type at $P<0.05(*)$ and $P<0.01(* *)$.

They also exhibited a decrease in leaf dry weight. On the other hand, GDH potatoes showed increases in tuber dry weight and total dry weight compared with the wild type. The tuber dry matter ratio of GDH potatoes was higher than that of the wild type under the low-nitrogen condition (Table 1).

\section{Nitrogen and carbon distributions of $G D H$ potatoes at tuber-bulking stage}

The nitrogen concentrations of leaves, stem and tubers of GDH potatoes under the control nitrogen condition were almost the same as those of the wild-type potato. We found the same trend under the low-nitrogen condition. In addition, the carbon concentrations of these parts of GDH potatoes and the wild type did not differ under control nitrogen and low-nitrogen conditions (data not shown).

On the other hand, nitrogen and carbon contents per plant differed between GDH potatoes and the wild type, particularly under the low-nitrogen condition. The nitrogen content in GDH potato leaves showed a tendency to decrease and that in tubers clearly increased. Carbon content in GDH potato leaves decreased and that in tuber increased, which was similar to the trends for dry matter as shown in Table 1 (Figure 4).

We calculated the ratio of nitrogen between plant top (stem + leaves) and tuber and the ratio of carbon between plant top (stem+leaves) and tuber. GDH potatoes had lower nitrogen top/tuber ratio than the wild type under both nitrogen conditions. GDH potatoes had significantly lower carbon top/tuber ratio than the wild type (Figure 5).

\section{Discussion}

\section{Enzyme activities of GDH potatoes}

We successfully introduced the A. nidulans gene, $g d h A$, as indicated by the genomic PCR analysis and by increases of NADP $(\mathrm{H})-\mathrm{GDH}$ activities in transgenic potato lines (Figure 1,2). The GDH potatoes had higher amination activities than deamination activities (Figure 2A, B). In vitro activities of $\mathrm{NADP}(\mathrm{H})-\mathrm{GDH}$ in $\mathrm{GDH}$ potato leaves were more than 10 -fold higher than those in the wild-type leaves (Figure 2A, B). This result indicates that the fungal $g d h A$ gene expressed in potato plants was functional. On the other hand, NAD(H)-GDH activities were at similar levels in GDH potato leaves and the wild-type leaves, suggesting that the introduction of fungal $g d h A$ gene did not affect the expression of endogenous $\mathrm{NAD}(\mathrm{H})-\mathrm{GDH}$ in transgenic potato plants. In a previous study, NADP(H)-GDH activities in $g d h A$ introduced rice leaves and roots were 1000- to 1500 - 

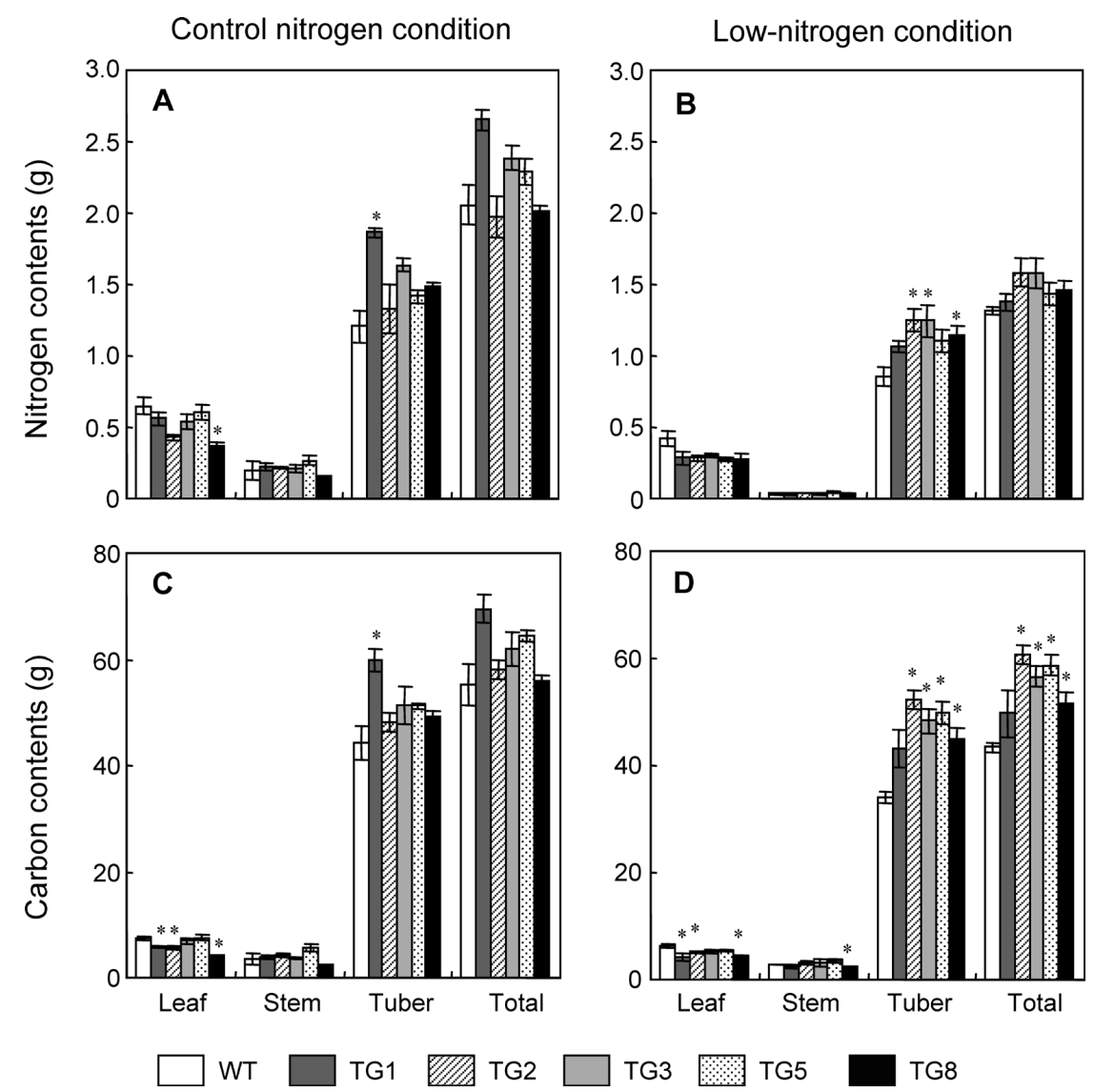

Figure 4. Nitrogen and carbon contents of wild-type and GDH potatoes. Nitrogen (A,B) and carbon (C,D) contents of leaves, stem, tubers and total contents under the control $(A, C)$ and low-nitrogen conditions $(B, D)$. Data represent the mean values \pm SE $(n=4)$. Asterisks indicate significant difference of the mean of each transgenic line from that of the wild type at $P<0.05(*)$.
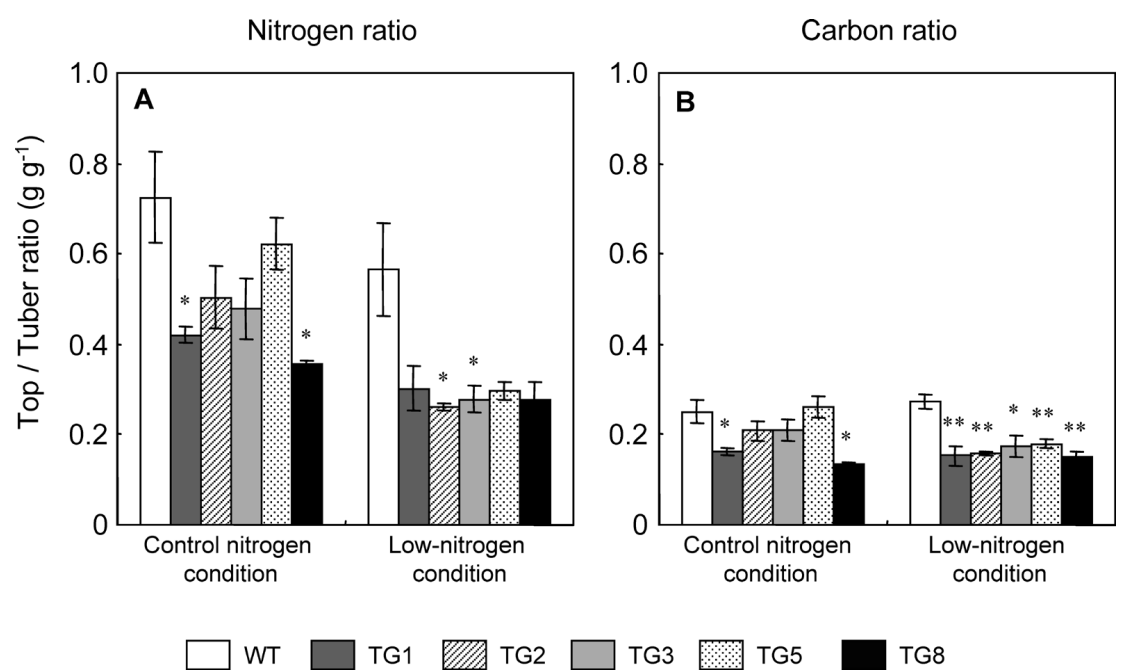

Figure 5. Top (stem+leaves)/tuber ratios of nitrogen (A) and carbon (B) of wild-type and GDH potatoes. Each ratio was calculated under control and low-nitrogen conditions. Data represent the mean values $\pm S E(n=4)$. Asterisks indicate significant difference of the mean of each transgenic line from that of the wild type at $P<0.05(*)$ and $P<0.01(* *)$.

fold and 400- to 700 -fold higher than those in wild-type leaves and roots, respectively (Abiko et al. 2010). In the leaves of $g d h A$-introduced tomato, there were 200- to 300 -fold higher activities than for the wild type (Kisaka and Kida, 2003). In the case of $g d h A$-introduced maize leaves, 10- to 10,000-fold higher activities than for the wild type were obtained (Lightfoot et al. 2007). Although GDH potatoes in this study showed a mild increase of 
NADP(H)-GDH activities compared with these findings in previous studies of $g d h A$ introduction, the effects on photosynthesis, biomass production and NUE were apparent.

\section{Increase of photosynthetic rates and biomass in GDH potatoes}

In the flowering stage of potato, the above-ground part of the plant grows vigorously and tuber formation starts underground. In the tuber-bulking stage, potato plants utilize assimilation products mainly for bulking tubers and accumulating starch in them. Therefore, we evaluated the properties related to source function, that is, photosynthetic rates, of GDH and wild-type potatoes at the flowering stage and the tuber-bulking stage.

GDH potato leaves showed higher photosynthetic rates and higher soluble protein concentrations than wild-type potato leaves at the flowering stage (Figure $2 \mathrm{C}, 3)$. These results suggest that the source leaves of $\mathrm{GDH}$ potato are more active in terms of carbon and nitrogen metabolism than those of the wild type, which may be due to increased nitrogen absorption and/or its partitioning into source leaves.

Here we showed that the tuber dry weight of potato improved upon the introduction of a fungal $g d h A$ gene, which is related to nitrogen absorption and metabolism. The tuber dry weight per plant increased in GDH potatoes in comparison with that in wild-type potatoes, particularly under the low-nitrogen condition (Table 1). The increase in tuber dry weight was mainly due to the increase in the number of tubers, not an increase in each tuber's weight (Table 1), suggesting that the expression of $g d h A$ might promote tuberization at the top of stolons. Photoassimilates such as sucrose are considered to promote tuberization. Therefore, in GDH potatoes, increased supply of photoassimilates from source leaves to sink tissues due to high photosynthetic rates might promote tuberization, resulting in the increased tuber number and, as a consequence, the increased tuber biomass.

Since potato tubers consist mainly of starch and sugars, genetic engineering of carbon metabolism, particularly the over-expression of genes for enzymes related to carbohydrate metabolism, has been considered useful for enhancing tuber yield. In fact, in a previous study, the over-expression of sucrose phosphate synthase, the key enzyme in the sucrose synthesis pathway, improved yield characteristics of potato (Ishimaru et al. 2008). The introduction of a fungal or bacterial $g d h A$ gene, encoding NADP $(\mathrm{H})-\mathrm{GDH}$, into crops was useful for improving yields in rice (Abiko et al. 2010), maize (Lightfoot et al. 2007) and tobacco (Ameziane et al. 2000), although increases of photoassimilates were not demonstrated in these previous studies. Given that the harvested parts of potato and tobacco are vegetative organs, while those of rice and maize are reproductive organs, $g d h A$ appears to be a powerful tool to improve the yield of crops, regardless of which organ is harvested for use.

\section{Nitrogen and carbon contents and NUE of GDH potatoes}

At the tuber-bulking stage, more than half of the nitrogen and carbon in potato accumulated in tubers under both control and low-nitrogen conditions (Figure 4). In general, the nitrogen redistribution from source to sink from the shoot-growing stage to the harvesting stage differs among plant species (Osaki et al. 1991). Potato has a high capacity to redistribute nitrogen to the sink at the harvesting stage compared with maize and rice. In our study, in the low-nitrogen condition, only tuber maintained its nitrogen concentration at the tuberbulking stage. When decreases of nitrogen concentration and content occurred in the leaf and stem under this condition, tuber nitrogen concentration was maintained by the vigorous nitrogen redistribution from leaf and stem. Furthermore, there were lower ratios of nitrogen and carbon in the plant top (stem+leaves) to those in tubers in GDH potatoes than in the wild type (Figure 5). This result suggested that GDH potatoes might have enhanced abilities to redistribute carbon and nitrogen to the sink.

To evaluate nitrogen utilization, we calculated NUE as the ratio of harvest dry weight to total absorbed nitrogen content. We also used tuber dry weight and total nitrogen content to represent harvest dry weight and total absorbed nitrogen, respectively. Both GDH potatoes and wild-type potatoes showed increases of NUE under the low-nitrogen condition (Figure 6). However, under both nitrogen conditions, GDH potatoes had higher NUE than the wild type. In addition, the difference in NUE between GDH potatoes and the wild type under the low-nitrogen condition was larger than that under the control nitrogen condition. The relationship between total absorbed nitrogen content and NUE is shown in Figure 6. Generally, NUE increased with a decrease of total absorbed nitrogen content. Figure 6 shows that NUE of GDH potatoes and the wild type increased as expected. However, the extent to which NUE increased for GDH potatoes appeared to be higher than that for the wild type, showing more efficient nitrogen use for tuber dry matter production by GDH potatoes than by the wild type under the low-nitrogen condition. Compared with other crops such as wheat or rice, potato has high NUE (Novoa and Loomos 1981). This result suggests that introduction of $g d h A$ can be a useful approach for controlling the NUE of potatoes, particularly under lownitrogen conditions.

In conclusion, potato with a fungal $g d h A$ gene showed enhanced source ability and increased tuber dry weight. 


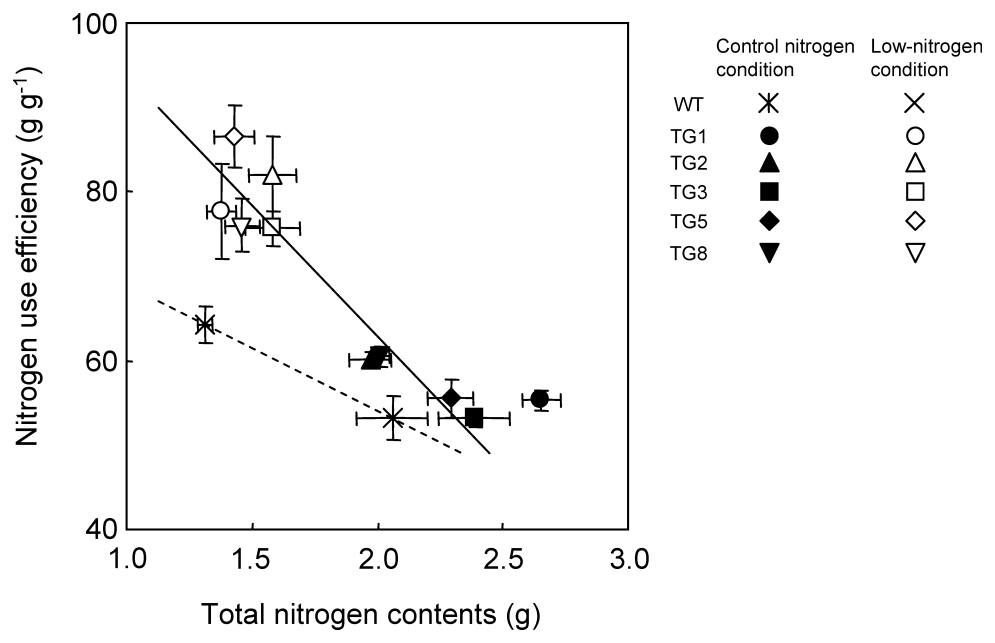

Figure 6. Correlation of NUE and total nitrogen contents of wild-type and GDH potatoes. Data represent the mean values \pm SE $(n=4)$.

Although the total nitrogen absorption of GDH potatoes increased, GDH potato tubers also showed much higher carbon content than those of the wild type. As a result, the GDH potatoes showed improved NUE. This study showed that the introduction of fungal gdhA gene improved the tuber dry matter production and NUE of potato.

\section{Acknowledgements}

This work was supported in part by grants from the Program for Promotion of Basic Research Activities for Innovative Biosciences (PROBRAIN).

\section{References}

Abiko T, Wakayama M, Kawakami A, Obara M, Kisaka H, Miwa T, Aoki N, Ohsugi R (2010) Changes in nitrogen assimilation, metabolism, and growth in transgenic rice plants expressing a fungal NADP(H)-dependent glutamate dehydrogenase $(g d h A)$. Planta 232: 299-311

Ameziane R, Bernhard K, Lightfoot D (2000) Expression of the bacterial gdhA gene encoding a NADPH glutamate dehydrogenase in tobacco affects plant growth and development. Plant Soil 221: 47-57

Aubert S, Bligny R, Douce R, Gout E, Ratcliffe RG, Roberts JK (2001) Contribution of glutamate dehydrogenase to mitochondrial glutamate metabolism studied by ${ }^{13} \mathrm{C}$ and ${ }^{31} \mathrm{P}$ nuclear magnetic resonance. J Exp Bot 52: 37-45

Bradford MM (1976) A rapid and sensitive method for the quantitation of microgram quantities of protein utilizing the principle of protein-dye binding. Anal Biochem 72: 248-254

Doyle JJ, Doyle JL (1990) Isolation of plant DNA from fresh tissue. Focus 12: 13-15

Ireland RJ, Lea PJ(1999) The enzymes of glutamine, glutamate, asparagine, and aspartate metabolism. In: Singh BK (ed) Plant amino acids: biochemistry and biotechnology. Marcel Dekker, New York, pp 49-109

Ishimaru K, Hirotsu N, Kashiwagi T, Madoka Y, Nagasuga K, Ono K, Ohsugi R (2008) Overexpression of a maize SPS gene improves yield characters of potato under field conditions. Plant Prod Sci 11: 104-107

Kanamori K, Weiss RL, Roberts JD (1987) Role of glutamate dehydrogenase in ammonia assimilation in nitrogen-fixing Bacillus macerans. J Bacteriol 169: 4692-4695

Kinghorn JR, Pateman JA (1973) NAD and NADP L-glutamate dehydrogenase activity and ammonium regulation in Aspergillus nidulans. J Gen Microbiol 78: 39-46

Kisaka H, Kida T (2003) Transgenic tomato plant carrying a gene for NADP-dependent glutamate dehydrogenase ( $g d h A)$ from Aspergillus nidulans. Plant Sci 164: 35-42

Lea PJ, Miflin BJ (1974) Alternative route for nitrogen assimilation in higher plants. Nature 251: 614-616

Lea PJ, Thurman DA (1972) Intracellular location and properties of plant L-glutamate dehydrogenases. J Exp Bot 23: 440-449

Lightfoot D, Mungur R, Ameziane R, Nolte S, Long L, Bernhard K, Colter A, Jones K, Iqbal M, Varsa E, Young B (2007) Improved drought tolerance of transgenic Zea mays plants that express the glutamate dehydrogenase gene E. coli. Euphytica 156: 103-116

Masclaux-Daubresse C, Reisdorf-Cren M, Pageau K, Lelandais M, Grandjean O, Kronenberger J, Valadier M-H, Feraud M, Jouglet T, Suzuki A (2006) Glutamine synthetase-glutamate synthase pathway and glutamate dehydrogenase play distinct roles in the sink-source nitrogen cycle in tobacco. Plant Physiol 140: 444-456

Novoa R, Loomis R (1981) Nitrogen and plant production. Plant Soil 58: $177-204$

Osaki M, Shinano T, Tadano T (1991) Redistribution of carbon and nitrogen compounds from the shoot to the harvesting organs during maturation in field crops. Soil Sci Plant Nutr 37: 117-128

Snyder GW, Belknap WR (1993) A modified method for routine Agrobacterium-mediated transformation of in vitro grown potato microtubers. Plant Cell Rep 12: 324-327

Vitousek PM, Aber JD, Howarth RW, Likens GE, Matson PA, Schindler DW, Schlesinger WH, Tilman DG (1997) Human alteration of the global nitrogen cycle: sources and consequences. Ecol Appl 7: 737-750

Wootton JC (1983) Re-assessment of ammonium-ion affinities of NADP-specific glutamate dehydrogenases. Activation of the Neurospora crassa enzyme by ammonium and rubidium ions. Biochem J 209: 527-531 